\section{PLANT ASSOCIATIONS IN MOORLAND} DISTRICTS.

DURING the last four years systematic observations have been made on the distribution of the various associations of vegetation covering the moorland region lying to the east of the Vale of Eden. ${ }^{1}$ The boundaries of each plant association have been traced out in the field and laid

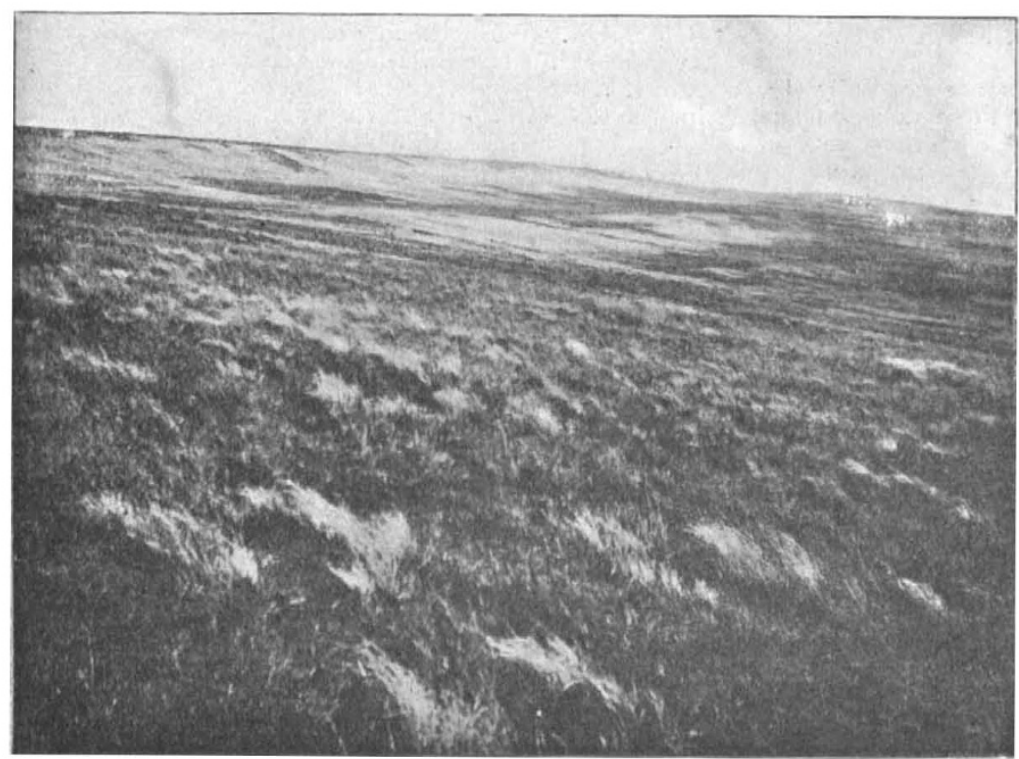

FIG. I.-Succession of moorland vegetation. Eriophortm Bog on the summit plateau. Nardus Grass Heath developed on the slopes below, changing to Grass Heath with Eriophorum as the wet, gently sloping foreground is reached. From the Geographical Journal.

down on the six-inch Ordnance map, and reduced to the one-inch map for publication. The factors governing the distribution of plant associations over such a limited area are mainly edaphic, although the differences in altitude, which amount to about 2500 feet in the area in question, produce changes in the vegetation which are chiefly due to climatic conditions. Much of the vegetation at present covering cultivated areas in Britain owes its distribution to artificial agencies, edaphic and climatic factors being to a great extent masked. The more remote moorland districts of the north of England and Scotland, however, give opportunities for studying plant associations the distribution of which is chiefly determined by edaphic and climatic factors, the artificial factors due to the influence of man being secondary.

The most important artificial agencies tending to modify the natural distribution of vegetation covering our moorlands at the present day appear to be drainage operations and grazing of cattle. On many of the alpine moorlands these factors are almost negligible, and any change in the vegetation has been caused, not by artificial agencies, but by secular changes in climate. The evidence of a change in vegetation, both on the alpine moorlands of England and Scotland, is unmistakable, and it is possible to a certain extent to reconstruct the waves of yegetation which have occupied the areas mentioned since the passing away of the last ice sheet.

1 "Geographical Distributions of the Vegetation of the Basins of the Rivers Eden, Tees, Wear and Tyne." (Geographical Journal, March and September, rgo4.)

$$
\text { No. I } 837 \text {, voL. } 7 \text { I] }
$$

The district in which mapping has been carried on by the author consists of a great extent of bleak, gently sloping moorland, of which about to per cent. lies above 2000 feet. The author has found that considerable and marked changes take place in the plant associations at about 2000 feet; tree vegetation ceases, and many alpine plants make their appearance which are absent from the lower moorlands.

The geological formation in the south and west of the district is chiefly Carboniferous limestone yielding only a small amount of detritus, whilst in the north and east the limestone thins out and is replaced to a great extent by sandstones, grits, and shales which yield a much larger amount of detritus. This feature has an important effect upon the vegetation, the wetter types of associations being developed upon those rocks yielding a large amount of detritus.

The moorlands first resolve themselves into two chief types, grass moorland and heather moorland, and these are frequently linked together by several intermediate plant associations. Dry heather moors or heaths do not cover any great extent of ground, and are chiefly found in the limestone districts of the south. The wetter types of heather moors are well developed, and the whole district can be briefly described as a wet heather and dry grass moorland country. These features are well shown in many of the " hopes" and gills leading out of Weardale and South Tynedale. The steep lower slopes of the hills are covered with an association having Nardus stricta as the dominant plant. Above I 500 feet to 1800 feet the slope of the ground becomes more gradual, and shales and grits make their appearance. At the same time the Nardus stricta association yields to heather associations in which Eriophorum is always a prominent plant. The

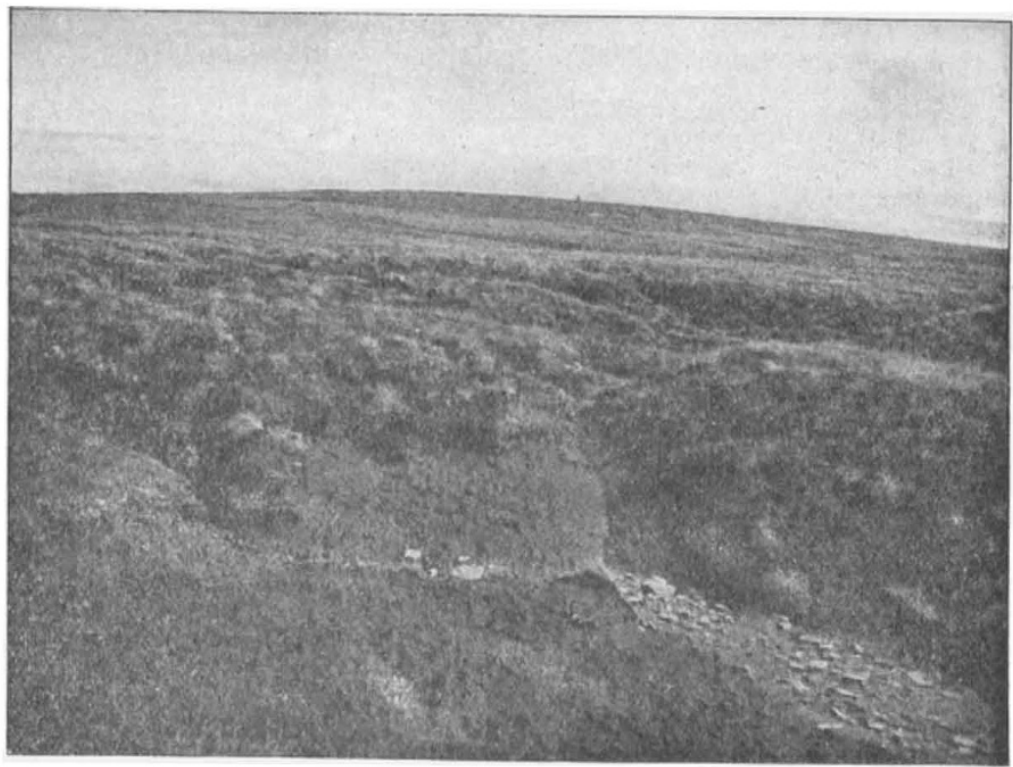

FIG, 2.-Calluna and Vaccinium association on a dry wind-swept summit at 2326 feet. The lowe vegetation developed on wet peat shows a great increase in Eriophorum. From the vegetation developed

succession of different types of moorland is often well shown along some of the "edges " in the north-east of the district. At Redbourne Edge the almost flat, poorly drained summit is entirely covered by Eriophorium bog, developed on deep wet peat. As the edge of the bog is approached the peat 
becomes drier, and Eriophorum is replaced by a narrow band of Calluna moor. Peat is absent on the slope below, and the ground is tenanted by Nardus grass heath, yielding to a wetter type of grass heath dominated by Molinia and Eriophorum. Such a succession of terraces of Eriophorum bog, Calluna moor, Nardus grass heath, and MoliniaEriophorum moor can be distinguished from a distance of many miles in the later months of the year, when the bleached Nardus stands out in vivid contrast to the sombre hued Calluna and Eriophorum associations.

The lower slopes of the alpine moorlands are generally covered by heather associations, which yield to pasture and grass heath as the summits are approached. The drier hills are covered by an association consisting of Calluna, Rubus Chamaemorus, Vaccinium Myrtillus, and V. Vitis-Idaea; the wetter hills are characterised by a much greater development of Eriophorum vaginatum and E. angustifolium.

The summits of the hills are generally tenanted by a few stunted members of the lower associations; in some cases, however, the vegetation only forms patches separated by bare stony soil or peat. Part of the summit plateau of Cross Fell at 2900 feet is entirely tenanted by Racomitrium lanuginosum, which forms low mounds of peat frequently broken by patches of stones and bare soil, a formation bearing a close resemblance to a moss-tundra of northern latitudes.

A considerable portion of the higher ground is covered with a deposit of peat varying in thickness from a few inches to nearly 20 feet. The peat appears to be undergoing rapid denudation at the present day-in many places large areas are quite unoccupied by vegetation, and exhibit the channelled and wasted appearance characteristic of peathags. These features can be seen on all the peat covered hills of the Pennines, the Cheviots, and the Scottish southern uplands, being particularly well marked on the Moorfoot Hills and in the Tweedsmuir district, and again appear in most of the peat districts of the Highlands. Many of the lowland mosses, particularly those bordering on the Solway Firth and along the west coast, exhibit no such denudation. How far the denudation of the mosses in the hill districts is due to drainage operations it is difficult to say, but the fact that the peat is generally wasted away quite as much on the more remote moorlands where artificial drainage has scarcely been carried on at all as on the drained areas lends strong support to the view that denudation is due to climatic changes. This is further supported by a detailed examination of the deeper peat beds, which frequently show many alternating beds of wet and dry condition plants. The peat beds on the Cross Fell chain are evidently of very ancient origin, as the author ${ }^{1}$ has found the remains of an Arctic flora at the base consisting of Arctic willows, and the peat above contains the remains of extensive woodlands up to an altitude of 2700 feet. The area in which woodland remains in the peat have been observed is about 140 square miles, whilst only ix square miles are forest clad at the present time.

Gunnar Andersson ${ }^{2}$ has shown that the destruction of some of the woodlands buried in the peat of Sweden has been caused by artificial retention of drainage water and a gradual exhaustion of food supply in the upper layers of the peat, thus bringing about a gradual swing from woodland conditions to moss conditions, and again to heath conditions. These causes may have produced alternations of woodland, moss, and heath in some of our low-lying mosses, but an examination by the author of the peat lying between the woodland beds suggests that the destruction of much of the buried forest growth has been due, not to local alterations in drainage and failure of food supply, but to climatic changes acting over very long periods of time.

Francis J. LEWIS.

THE ABNORMAL TIDES OF JANUARY 7 .

A $\mathrm{N}$ abnormally high tide was experienced down the east coast of Britain on Saturday last, January 7, extensive areas being flooded and considerable destruction wrought At 6 p.m. on Friday, January 6 , as shown in the Meteorological Office reports, a very deep cyclonic system appeared over the upper part of the North Sea, the baro1 British Association Reports, 1904, Section K.

2 "Svenska Vaxtvarldens Historia," (Stockholm.)

ㅇ. 1837 , VOL. $7 \mathrm{I}]$ meter at Sumburgh Head having fallen quickly to 28.7 inches. There was a steep gradient for north-westerly winds, and in the course of the night a more or less severe gale from that quarter was experienced over the North Sea, and as the south-going tide from the Pentland Firth was then on the flood, both its velocity and its volume were greatly increased, so that it reached the Thames estuary some hours ahead of its time, and was several feet above the calculated height. While the low barometer of Friday night may have caused the tide level in the far north to have been raised about a foot, the very rapid increase of pressure to 29.83 inches at 8 a.m. on Saturday at Sumburgh Head, a rise of $I_{1} I_{3}$ inches in fourteen hours, may have done something towards swelling the volume of the tide further south. Except for the hard gale, the conditions were very similar to those which prevailed with the great tide experienced on the southern and south-western coasts at the beginning of February, 1904 (NATURE, vol. 1xix. p. 348).

Much damage was done all along the coast from Scarborough to the Thames. At the former place the pier was entirely washed away, and at Hull, Goole, Boston, Yarmouth and Lowestoft, and other places the low-lying parts of the towns were flooded. The damage was not due to unusual violence of the wind alone, but to the combined effects of wind and tidal waves. From the returns of the Meteorological Office it appears that the force of the gale from Wick to Yarmouth varied from 7 to 10 on the Beaufort scale. The tide was the third after the new moon, and laid down in the tide tables as less than a full springtide. At Boston 28 feet 5 inches was recorded on the gauge at the dock, or 116.47 feet above Ordnance Datum, being 4 feet 8 inches above the height expected. The following tide in the evening was $2 \mathrm{I}$ feet $\mathrm{II}$ inches, or I foot 1o inches below the tide table height, the difference in the two tides being 6 feet 6 inches. The highest tide recorded there previously was in 1883 , when the tide rose to 29 feet, the great record tide of 1810 rising to 29 feet 4 inches. Notwithstanding the great height to which the tide rose, it ceased flowing nearly half an hour before its proper time.

The tidal wave had fortunately somewhat expended its energy before reaching the Thames, but the water was in a very disturbed condition. By mid-day the water at Putney Bridge had risen as high as it should have been at full tide, which was not due until 3.45. At 1.30 it was a foot higher than any spring tide in recent years. Shortly after this the water began to recede, and continued to do so for half an hour. Then the water again rose, and at 3.I 5 the ebb again set in. The water in the Thames and Medway estuaries was kept from receding by the gale, and on the morning of Saturday it was 8 feet above its normal height. At 9 a.m., when the tide had still $4^{\frac{3}{4}}$ hours to flow, it was running up the Medway 6 feet above the anticipated height at this stage. By I o'clock the level of high water was reached, but during the remaining $2 \frac{3}{4}$ hours the flow was very slight compared with the earlier stages, and although the water rose from 2 to 3 feet above the normal height, there was no overflow or breaches in the banks.

\section{THE ELECTRO-THERMIC MANUFACTURE OF IRON AND STEEL.'}

THIS report is of great interest and importance to iron and steel metallurgists, and the appointment of the commission which has drawn it up suggests that Canada has an enterprise in fostering metallurgical knowledge which the Government of the mother country might well imitate for the advantage of British metallurgical industries. The English metallurgist attached to the commission was $\overline{M r}$. F. W. Harbord.

Three processes were experimentally examined:-(I) the Kjellin process at Gysinge, Sweden (this is an induction process not involving the use of electrodes) ; (2) the Herroult process at La Praz, France (this is a resistance method involving the use of electrodes); (3) the Keller process (also a resistance method in which electrodes are employed).

On p. I5 of the report Dr. Eugene Haanel, the chief

1 " Report of the Commission appointed by Mr. Clifford Sifton, Minister of the Interior, Ottawa, Canada, to Investigate the Different Electro-thermic Processes for the Smelting of Iron Cres and the Making of Steel in Europe." (Ottawa : Department of Interor.) 